\title{
ANALISIS MANAJEMEN KEUANGAN USAHA PETERNAKAN KEMITRAAN AYAM BROILER SKALA RAKYAT
}

\author{
Taufan Daniarta Sukarno $\left.{ }^{1^{*}}\right)$ \\ ${ }^{1}$ Kementerian Desa, Pembangunan Daerah Tertinggal dan Transmigrasi
}

*Corresponding author : taufands@gmail.com

To cite this article:

Sukarno, T. (2020). Analisis Manajemen Keuangan pada Usaha Peternakan Kemitraan Ayam Broiler Skala Rakyat. Jurnal Ilmiah Membangun Desa dan Pertanian, 5(1), 37 - 44. doi:http://dx.doi.org/10.37149/jimdp.v5i1.10628

Received: January 24, 2020; Accepted: February 14, 2020; Published: February 16, 2020

\begin{abstract}
Poultry sectors contributed 2,51\% of GDRP in the Central Java Province, where Semarangcontributed $1.135 .487 \mathrm{~kg}$ of Broilers chicken in 2016. Plasma-core partnership is one of the most used business cooperation types amongst the poultry farmers. Classification in poultry business scale divides into 3 classes, which were: Small Scale ( $\leq 5.000$ heads), Medium Scale (5.001-10.000 heads) and Large Scale (>10.000 head). The purpose of this study is to estimate the operating cashflows and revenue. The benefit of this study is to detect the profits and anticipate losses in poultry farming. This study used Survey methods, location arrangement used purposive sampling and data collected by interviews with the owners. Data analysis used revenue and operating cash flow computation. The results of this study show the net revenue of this poultry farm is IDR.171.488.834, while the operating cash flows are IDR.170.286.117,65. The cost of chicken seedlings purchase and its feed is the most expensive amongst all subjects. Clustering results shows that this poultry was categorized as Small scale poultry, where it's population is only 4.000 chickens, but are profitable and worthy to expand, and makes it one of the most longest-living poultry farms in the region
\end{abstract}

Keywords : farming; financial; husbandry; management; poultry

\section{PENDAHULUAN}

Sektor Peternakan merupakan salah satu komoditas yang paling banyak diusahakan dan memiliki impak yang cukup tinggi terhadap perekonomian di Provinsi Jawa Tengah. Hal tersebut dapat dilihat dari beberapa indikator, menurut data BPS (2017) kontribusi penyerapan tenaga kerja sektor peternakan Provinsi Jawa Tengah berjumlah lebih dari 1.2267 orang, kontribusi sektor peternakan terhadap PDRB Provinsi mencapai 2,51 persen (2015), dan Nilai Tukar Petani (NTP) subsektor peternakan Provinsi Jawa Tengah selalu diatas nilai 100 (2016). Kota Semarang menjadi pusat perekonomian sekaligus perputaran uang terbesar di Provinsi Jawa Tengah. Hal ini tentunya juga berdampak pada tingkat permintaan dan penawaran komoditas peternakan baik di wilayah Kota sendiri maupun wilayah Kabupaten / Kota sekitar. Pada peternakan unggas, sesuai dengan data BPS (2017) jumlah produksi ayam petelur, pedaging dan ayam bukan ras di Kota Semarang secara berturut-turut adalah sebesar $238.305 \mathrm{~kg}, 16.049 .681 \mathrm{~kg}$ dan $1.135 .487 \mathrm{~kg}$. Tinggi nya angka produksi ayam pedaging broiler menjadi poin utama yang menarik untuk dibahas tentang kondisi eksisting dan potensi pengembangan peternakan unggas skala kecil di Kota Semarang.

Pola kemitraan pada usaha peternakan dapat didefinisikan sebagai perjanjian kerjasama antara 2 usaha di sektor peternakan, antara perusahaan inti yang bergerak pada sisi hulu dan hilir (penyedia sarana produksi dan tempat penjualan hasil produksi) dan peternak plasma yang bekerja pada sisi penyiapan lokasi dan pembesaran ternak (Paly, 2016). Pola kemitraan diharapkan menjadi simbiosis mutualisme antara satu sama lain karena akan saling membutuhkan dan saling menguntungkan. Dalam sebuah usaha peternakan unggas skala rakyat, terdapat tingkatan yang menstratifikasi skala usaha tersebut. Menurut Utomo et al (2015), stratifikasi usaha peternakan dibagi berdasarkan jumlah populasi ternak, yaitu : (a) strata I, dengan populasi ayam kurang dari 4.000 
ekor; (b) strata II, dengan populasi antara 4.001 sampai dengan 8.000 ekor ayam; dan (c) strata III, dengan populasi lebih dari 8.000 ekor ayam.

Proses pengusahaan suatu peternakan, tentunya peternak harus mampu mengestimasi proyeksi keuntungan yang didapat dan pengeluaran yang dikeluarkan selama proses budidaya. Maka dari itu, perlunya dibutuhkan suatu pola manajemen keuangan yang terstruktur dan baik. (Harjito dan Martono 2010) Manajemen keuangan dapat didefinisikan sebagai semua kegiatan perusahaan yang bertujuan untuk memperoleh keuntungan, mengelola modal dan asset untuk mencapai tujuan perusahaan. Manajemen keuangan di sektor pertanian dapat didefinisikan sebagai suatu keseluruhan aktivitas yang berhubungan dengan usaha untuk mengatur keuangan secara terencana, terarah dan terkendali dengan menggunakan dana / modal seefisien mungkin untuk mengelola faktorfaktor produksi pertanian yang dibutuhkan dengan tujuan akhir mencapai keuntungan dari usaha pertanian yang dilakukan.

Manajemen keuangan, 2 komponen utama yang mampu melihat kesehatan kondisi keuangan sebuah usaha adalah pada pendapatan dan operating cashflow. Pendapatan didefiniskan sebagai hasil produksi dikurangi dengan biaya-biaya yang dikeluarkan (Ratnasari et al., 2015). Komponen kedua adalah operating cashflow atau arus kas. Arus kas, bersama dengan laporan laba rugi, menjadi salah satu indicator yang menunjukkan tingkat sehat tidaknya sebuah usaha dalam melakukan bisnisnya (Zuhairoh et al 2019).

Penelitian yang melatarbelakangi dalam penulisan ini adalah hasil penelitian dari Utomo et al (2015) yang berjudul "Analisis Profitabilitas Usaha Peternakan Ayam Broiler Dengan Pola Kemitraan di Kecamatan Limbangan Kabupaten Kendal". Dalam penelitian tersebut dijabarkan tentang perhitungan keuntungan yang didapatkan oleh usaha peternakan ayam broiler dengan skema kemitraan inti-plasma. Hasil dan kesimpulan dari penelitian tersebut adalahmasing-masing strata usaha memiliki tingkat keuntungan tersendiri dimana jumlah populasi menjadi faktor utama yang mempengaruhi biaya produksi, penerimaan dan pendapatan yang diperoleh peternak plasma.

Ruang lingkup dalam manajemen keuangan dalam penelitian ini terdiri dari keputusan investasi dan pengelolaan asset usaha. Sesuai dengan pendapat Harjito dan Martono (2010) yang menyatakan bahwa 3 fungsi dari Manajemen Keuangan adalah keputusan investasi, keputusan pendanaan dan pengelolaan asset. Tujuan dari studi ini adalah untuk menganalisis manajemen keuangan usaha peternakan, yaitu dengan menghitung arus kas dan menghitung pendapatan yang diterima pada suatu usaha peternakan ayam broiler kemitraan plasma skala kecil. Manfaat dari studi ini adalah agar dapat memproyeksikan keuntungan dan mendeteksi kerugian pada sebuah usaha peternakan

\section{MATERI DAN METODE}

Penelitian dilaksanakan pada bulan Desember 2019 bertempat di peternakan ayam broiler milik bapak Sariman di Kelurahan Jatirejo, Kecamatan Gunung Pati, Semarang. Penentuan lokasi bersifat purposive dengan pertimbangan dari peneliti dalam pemilihan lokasi adalah bahwa usaha ini merupakan usaha peternakan skala rakyat dengan pola kemitraan inti plasma yang sudah berdiri cukup lama dibandingkan dengan usaha lain, dan dapat dikategorikan sebagai pioneer usaha serupa di wilayah yang tersebut. Metode penelitian menggunakan metode survey. Pengambilan data primer dilakukan dengan wawancara langsung terhadap pemilik dan pengurus peternakan. Analisis data menggunakan metode deskriptif kuantitatif, yaitu dilakukan dengan menarasikan data yang telah diolah secara perhitungan kuantitatif.

Data primer yang dicari berupa jumlah biaya investasi, biaya produksi (biaya tetap + biaya variabel) dan penerimaan. Merujuk pada pendapat Kurniawati et al (2012), untuk melihat standar akuntansi keuangan, 5 asas utamanya adalah: neraca, laporan laba-rugi, perubahan modal, arus kas dan laporan keuangan. Dalam penelitian ini, data primer yang didapat kemudian diolah dengan menggunakan rumus perhitungan yang berkaitan dengan analisis keuangan, yaitu mencari jumlah pendapatan usaha dan operating cashflow. Rumus yang digunakan dalam penghitungan adalah :

Pendapatan $=$ Penerimaan - Biaya Produksi (Biaya variabel + Biaya tetap)

Operating Cashflow =Pendapatan Setelah Pajak + Depresiasi + Bunga $(1-$ Pajak $)$

\section{HASIL DAN PEMBAHASAN}

\section{Kondisi Umum Usaha}

Berdasarkan hasil observasi lapangan yang dilakukan, Peternakan unggas ini dimiliki oleh peternak bernama Bapak Sariman (54 tahun) yang bertempat di Kelurahan Jatirejo, Kecamatan Gunung Pati, Semarang. Hasil penelitian Ratnasari et al. (2015) menemukan bahwa di Kecamatan 
Gunung Pati terdapat banyak peternak ayam dengan pola kemitraan dibandingkan Kecamatan lain di Kota Semarang. Usaha ini didirikan oleh beliau pada tahun 2009, awalnya dengan menggunakan modal sendiri. Setelah lebih kurang 2 tahun berjalan dengan cara konvensional, beliau mulai menjalin kerjasama dengan suatu perusahaan inti di sektor peternakan ayam broiler.Bapak Sariman sebagai peternak membangun infrastruktur kandang secara pribadi sebagai tempat usaha beserta fasilitas lain untuk penunjang (sumur, pembuangan dan pengolahan kotoran, gudang), sementara perusahaan sebagai mitra inti mensuplai berbagai kebutuhan sarana produksi ternak (sapronak) seperti bibit, vaksin, obat2an dan pakan, juga sebagai pembeli utama hasil panen, sehingga semua hasil panen milik peternakan ini langsung dibeli oleh mitra inti nya, sehingga petani memiliki kepastian penjualan.

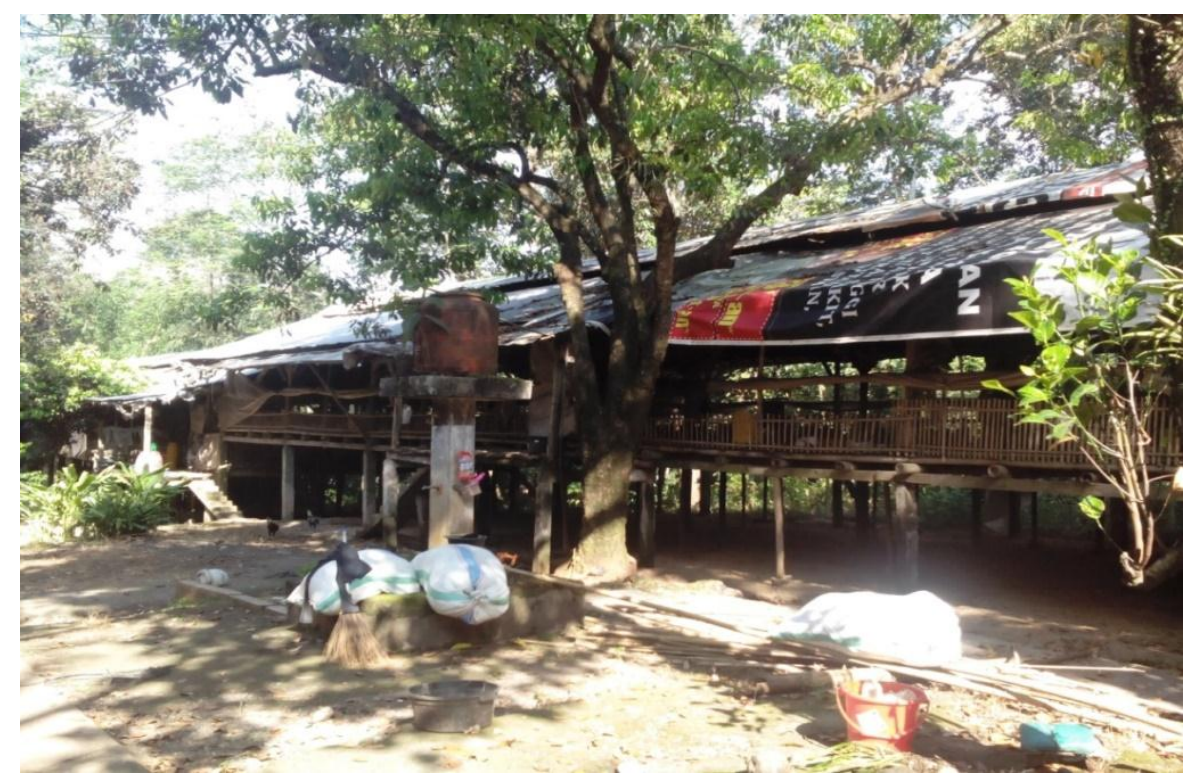

Gambar 1. Lokasi kandang pembesaran ayam milik Bapak Sariman (Sumber : Data Primer, 2019)

Lokasi peternakan ini cukup jauh dari pemukiman penduduk, tetapi memiliki akses transportasi jalan yang cukup mudah untuk diakses, mengangkut ataupun memasarkan ayam. Letak kandang juga tidak jauh dari sumber air sehingga sanitasi dan desinfektasinya terjamin. Kandang dibangun dengan tipe panggung, berbahan dasar bambu untuk lantai, dan setengah tinggi dinding, sementara dinding sisanya menggunakan kawat. Struktur atap berbentuk segitiga menggunakan bahan dasar seng yang dilapisi dengan terpal yang ditujukan untuk mengantisipasi suhu tinggi . Menurut Fadilah (2012), penggunaan seng yang dilapisi dengan bilik (slat) bambu lebih ideal untuk menghambat panas berlebih. Kandang memiliki ukuran sebesar $25 \times 8$ meter persegi, dengan tinggi antara tanah dengan lantai panggung setinggi 2 meter. Sesuai dengan pendapat Jayanata dan Harianto (2011) ketinggian ideal dari tanah hingga alas kandang adalah 1,75-2 meter. Saat ini usaha peternakan ayam milik Bapak Sariman memuat sebanyak 4.000 ekor ayam tipe pedaging (broiler) dalam 1x masa pembesaran (35 hari). Dalam kepengurusan peternakan sehari-hari, beliau bertumpu pada anak kandang untuk mengurus segala keperluan dalam pembesaran ternak. Pencatatan biaya pemasukan dan pengeluaran hanya pada 2 fase, awal ketika pembelian dan akhir ketika panen, sementara selama fase pembesaran tidak dihitung. Potensi timbulnya pengeluaran dan pemasukan yang tidak terdeteksi dalam penghitungan akhir dirasa cukup tinggi serta dapat mempengaruhi nominal pendapatan bersih usaha. Pembukuan dalam usaha peternakan ini masih menggunakan cara konvensional, yaitu dengan menggunakan buku catatan dan smartphone dan dengan perhitungan yang sederhana.

\section{Penerimaan}

Menghitung pendapatan yang diterima oleh usaha, yang perlu dicari adalah penerimaan dan total biaya produksi. Dalam menghitung jumlah penerimaan usaha pembesaran ayam broiler, dijabarkan pada Tabel 1. 
Tabel 1. Penghitungan penerimaan selama 1 tahun

\begin{tabular}{ccccc}
$\begin{array}{c}\text { Populasi } 1 \mathrm{x} \text { masa } \\
\text { pembesaran }\end{array}$ & $\begin{array}{c}\text { Masa } \\
\text { Pembesaran } \\
\text { dalam 1 tahun }\end{array}$ & Total & Harga Jual & Penerimaan \\
\hline 3.800 (ekor) & 8 (kali) & 30.400 (ekor) & Rp.16.000 (per ekor) & Rp.486.400.000 \\
\hline
\end{tabular}

Sumber : Data Primer diolah, 2019.

Berdasarkan Tabel 1, didapatkan hasil bahwa penerimaan peternak dalam kurun waktu 1 tahun adalah sebesar Rp.486.400.000. Dalam 1 tahun berjalan, usaha ini mampu berproduksi ratarata 8x panen, dimana 1 masa pembesaran berkisar antara 28 - 35 hari (4-5 minggu). Sesuai dengan pendapat Yemima (2014), dimana kelebihan dari ayam broiler adalah dapat dibudidayakan dalam siklus yang cukup singkat yaitu 4-6 minggu dengan bobot akhir antara 1,4-1,6 kg/ekor. Dalam 1x masa pembesaran, peternakan ini memiliki kapasitas sebanyak 4.000 ekor ayam tipe pedaging (broiler), namun jumlah tersebut direduksi 5\% untuk mengantisipasi tingkat mortalitas (kematian) dan panen yang tidak sesuai standar (afkir, cacat), sehingga didapatkan kisaran angka 3.800 ekor. Penentuan nilai mortalitas berdasarkan dari hasil penelitian Subkhie et al (2012) yang mengasumsikan rata-rata tingkat kematian / deplesi ayam selama masa pemeliharaan sebesar $4 \%$. Setelah itu, kandang akan mengalami proses kering kandang, yaitu proses membersihkan kandang dan penyiapan kandang untuk digunakan kembali agar terhindar dari penyakit yang dibawa ternak sebelumnya. Rata-rata proses kering kandang adalah 1-2 minggu. Sehingga total masa pembudidayaan (pembesaran + kering kandang) adalah 6-7 minggu. Apabila dibagi dalam 1 tahun, maka dalam 1 tahun tersebut peternakan ini mampu melakukan 8 kali masa pembudidayaan.

Rata-rata produksi bibit ayam broiler untuk 1 tahun mencapai 30.400 ekor. Harga jual ayam per ekor di Provinsi Jawa Tengah seharga Rp.16.000 (estimasi rata-rata), Penggunaan nilai jual ayam broiler dewasa rata-rata menggunakan standar Provinsi Jawa Tengah dikarenakan antar pengusaha ternak inti dan perusahaan plasma sudah memiliki harga jual sendiri yang diteken dalam sebuah kontrak bersama, sehingga peneliti menggunakan harga pasar yang lebih bersifat umum. (Ratnasari et al., 2015) menyatakan jika usaha peternakan mitra-plasma merupakan kerjasama saling menguntungkan antar kedua belah pihak, dimana didalamnya termasuk kedalam kesepakatan penjualan hasil panen kepada mitra. Pada umumnya, peternak inti-plasma mendapat harga yang lebih baik dibandingkan peternak lain / konvensional. Hasil ini sesuai dengan penelitian Suwarta et al (2012) bahwa peternak inti-plasma mendapat harga sarana produksi ternak lebih rendah dan harga jual panen yang lebih baik dibandingkan dengan peternak mandiri.

\section{Biaya Produksi}

Biaya produksi merupakan semua biaya yang dikeluarkan untuk membuat sebuah perusahaan dapat berjalan. Biaya produksi terdiri dari jumlah antara biaya tetap dengan biaya variable. Biaya tetap terdiri dari biaya penyusutan perlengkapan yang dimiliki serta biaya gaji pegawai. Biaya variabel meliputi biaya pembelian bibit ayam DOC (day old chicks), biaya pakan, obat-obatan dan vaksin, biaya listrik, serta biaya air. Perhitungan biaya produksi dilakukan dalam kurun waktu 1 tahun produksi (12 bulan) yang dijabarkan pada Tabel 2 .

Tabel 2. Biaya Produksi usaha ternak

\begin{tabular}{lrrr}
\multicolumn{1}{c}{ Biaya } & \multicolumn{1}{c}{ Jumlah } & Harga satuan (Rp) & \multicolumn{1}{c}{ Total (Rp) } \\
\hline Biaya Variabel & & & \\
- Biaya bibit ayam & 32.000 (ekor) & 5.300 & 169.600 .000 \\
- Biaya pakan & 38,4 (ton) & 3.000 .000 & 115.200 .000 \\
- Biaya vaksin / obat & 8 (set) & 950.000 & 7.600 .000 \\
- Biaya listrik & 8 (bulan) & 350.000 & 2.800 .000 \\
- Biaya air & 8 (bulan) & 150.000 & 1.200 .000 \\
\hline Jumlah & & & 296.400 .000 \\
\hline Biaya Tetap & & \\
- Biaya Penyusutan & 1 orang (12 bulan) & \\
- Gaji Anak Kandang & Jumlah & 1.500 .000 & 18.000 .000 \\
\hline & & & 314.512 .166 \\
\hline
\end{tabular}

Sumber : Data Primer diolah, 2019. 
Berdasarkan hasil penghitungan biaya produksi yang diperoleh, total biaya produksi yang dikeluarkan adalah sebesar Rp. 314.912.166 per tahun. Rincian komponen biaya produksi berupa : (a) bibit ayam DOC, memiliki harga kisaran Rp.5.300/ekor untuk penjualan di kawasan Jawa Tengah, maka dari itu, biaya pembelian bibit ayam broiler dalam 1 tahun sejumlah 32.000 ekor adalah sebesar Rp.169.600.000. Dalam penelitiannya, Ratnasari et al., (2015) menyebut bahwa biaya bibit DOC merupakan salah satu komponen terbesar dalam usaha peternakan broiler, namun semakin banyak bibit DOC, akan menambah hasil panen sehingga penerimaan juga akan bertambah; (b) Biaya pakan, dengan estimasi rata-rata dalam 35 hari masa pembesaran 1 ekor ayam akan menghabiskan pakan sebanyak 1,2 kilogram, dalam 1 tahun akan menghabiskan sebanyak 38,4 ton. Harga $100 \mathrm{~kg}$ pakan ayam (2 sak) adalah sebesar Rp.300.000. Maka total biaya untuk pakan ternak adalah sebesar Rp.115.200.000 selama 8x masa pembesaran. Besarnya nominal biaya pakan sesuai dengan hasil penelitian yang dilakukan oleh Nurmi et al (2018), dimana selain bibit, pengeluaran terbesar dari peternakan adalah biaya pakan, antara $60 \%-80 \%$ dari total biaya produksi. Biaya (c) Obat-obatan dan vaksin, pemberian vaksin dan obat kepada ayam menggunakan vaksin tetes, suntik dan melalui air minum, nominal biaya vaksin adalah sebesar Rp. 7.600.000. Hasil penelitian Suwarta et al (2012) menyatakan bahwa besaran biaya obat-vitamin-kimia (OVK) mengikuti jumlah populasi ternak yang dibudidayakan; (d) Biaya listrik, menggunakan nilai tarif dasar listrik (TDL) tahun 2019, yaitu sebesar Rp.1.500 / kWH sebagai basis penghitungan dan kebutuhan listrik rata-rata sebanyak $230 \mathrm{kWH}$ selama 1 masa pembesaran, adalah sebesar Rp.2.800.000; dan (e) Biaya air, menggunakan perhitungan rata-rata konsumsi air minum untuk ayam adalah 125 liter / 1000 ekor / hari adalah Rp.1.200.000 per tahun.

Biaya tetap didefinisikan sebagai biaya yang pasti dikeluarkan oleh usaha selama produksi, dihitung dalam kurun waktu 1 tahun. Komponen biaya tetap terdiri dari (a) pengeluaran untuk gaji 1 orang anak kandang (pengurus peternakan sehari-hari) sebesar Rp.1.500.000 per bulan atau Rp.18.000.000 per tahun; dan (b) biaya penyusutan yang berjumlah Rp.512.166,65 per tahun. Adapun penghitungan biaya penyusutan dijabarkan pada Tabel 3.

Tabel 3. Penghitungan nilai penyusutan usaha

\begin{tabular}{|c|c|c|c|c|c|c|}
\hline Nama Barang & Jumlah & $\begin{array}{l}\text { Harga/ unit } \\
\text { (Rp) }\end{array}$ & $\begin{array}{l}\text { Harga Awal } \\
\text { (Rp) }\end{array}$ & $\begin{array}{c}\text { Umur } \\
\text { Eknomis } \\
\text { (tahun) }\end{array}$ & $\begin{array}{l}\text { Harga Akhir } \\
\text { (Rp) }\end{array}$ & $\begin{array}{l}\text { Penyusutan/ } \\
\text { tahun (Rp) }\end{array}$ \\
\hline Tempat pakan & 5 & 23.000 & 115.000 & 6 & 105.000 & $1.666,65$ \\
\hline $\begin{array}{l}\text { Tempat minum } \\
\text { otomatis }\end{array}$ & 5 & 65.000 & 325.000 & 6 & 275.000 & $8.333,35$ \\
\hline Baby Feeder & 5 & 13.000 & 65.000 & 6 & 55.000 & $1.666,65$ \\
\hline Pemanas & 1 & 22.000 & 22.000 & 6 & 19.000 & 500 \\
\hline Kandang & 1 & 60.000 .000 & 60.000 .000 & 10 & 55.000 .000 & 500.000 \\
\hline Lahan & $675 \mathrm{~m}^{2}$ & 18.500 .000 & 18.500 .000 & - & - & - \\
\hline $\begin{array}{l}\text { Bibit ayam } \\
\text { periode } 1\end{array}$ & $\begin{array}{l}4.000 \\
\text { ekor }\end{array}$ & 5.300 & 21.200 .000 & - & - & - \\
\hline $\begin{array}{l}\text { Pakan ayam } \\
\text { periode } 1\end{array}$ & 1 ton & 6.950 & 6.950 .000 & - & - & - \\
\hline Total & & & 100.227 .000 & & 139.704 .000 & $512.166,65$ \\
\hline
\end{tabular}

Sumber : Data Primer diolah, 2019.

Berdasarkan tabel 3, dapat diketahui bahwa biaya penyusutan dari usaha peternakan ayam broiler milik bapak Sariman memiliki nilai penyusutan sebesar Rp.512.166,65 per tahun. Penghitungan penyusutan dilakukan berdasarkan harga beli awal barang, estimasi umur ekonomis barang, dan estimasi harga akhir barang. Menggolongkan nilai penyusutan kedalam biaya tetap sesuai dengan pendapat Fatoni (2014) yang menyatakan bahwa komponen biaya tetap dalam peternakan meliputi penyusutan kandang dan penyusutan peralatan. Besarnya biaya penyusutan dipengaruhi oleh harga perolehan, umur ekonomis, atau masa manfaat dan nilai aktiva. Penghitungan nilai depresiasi pada penelitian ini bertujuan untuk mengalokasikan beban dari aset yang dibeli agar sesuai dengan perkiraan masa pakainya. Hasil penelitian Jaelani et al., (2013) menyebutkan bahwa penyusutan termasuk kedalam biaya tetap, yang terdiri dari penyusutan kandang dan peralatan peternakan.

\section{Pendapatan Usaha}

Perhitungan pendapatan yang diterima usaha dalam kurun waktu 1 tahun dijabarkan pada rumus dibawah : 
Pendapatan per tahun $=$ Penerimaan - Biaya Produksi (Biaya variabel + Biaya tetap)

= Rp.486.400.000 - Rp. 314.912.166

$=$ Rp. 171.488 .834

Sesuai dengan rumus diatas, maka jumlah pendapatan yang diterima dari usaha peternakan ayam broiler milik bapak Sariman selama 1 tahun adalah sebesar Rp. 171.488.834. Jika dibagi berdasarkan jumlah masa pembesaran ( 8 kali), maka tiap kali pembesaran pemilik usaha menghasilkan keuntungan bersih sebesar Rp.21.436.104. Nominal ini menunjukkan pendapatan bersih yang diterima mampu digunakan untuk modal pada periode pembesaran berikutnya. Menurut Utomo et al (2015), besar kecilnya pendapatan yang diperoleh oleh peternak adalah didasarkan dari jumlah penerimaan dengan biaya produksi, dimana semakin besar pendapatan, menunjukkan produksi semakin efisien dan layak untuk mengembangkan usaha. Dengan menunjukkan kondisi usaha yang memberi keuntungan, keberlangsungan usaha peternakan ini tergolong kedalam kondisi baik dan layak untuk pengembangan selanjutnya. Jika didasarkan pada populasi ternak, dengan populasi sebanyak 4.000 ekor tiap 1 kali masa pembesaran, usaha ini tergolong kedalam strata 1 , yaitu peternakan kemitraan Skala kecil Penggolongan ini merujuk pada penelitian yang dilakukan oleh (Edwina dan Cepriadi, 2007) yang mengkategorikan bahwa pada peternakan plasma, penggolongan dikelompokkan berdasarkan jumlah pemeliharaan ayam menjadi 3 kelompok, yaitu: (a) Skala Kecil, dengan populasi ternak $\leq 5.000$ ekor; (b) Skala sedang, dengan populasi 5.001 - 10.000 ekor; dan (c) Skala Besar > 10.000 ekor.

\section{Operating Cashflow}

Perhitungan nilai Arus kas berjalan (operating cashflow), maka perlu dicari dahulu nilai pendapatan setelah pajak (Earning After Tax), yang akan dijabarkan pada Tabel 4.

Tabel 4. Penghitungan pendapatan setelah pajak

\begin{tabular}{lr}
\hline \multicolumn{1}{c}{ Komponen } & Nominal \\
\hline Penerimaan & $R p .486 .400 .000$ \\
Biaya Variabel & $R p .296 .400 .000$ \\
Biaya Tetap & $R p .18 .512 .166,65$ \\
\hline Earning Before Interest and Tax (EBIT) & $R p .171 .488 .834$ \\
Biaya bunga & 0 \\
\hline Earning Before Tax (EBT) & $R p .171 .488 .834$ \\
Pajak 1\% & $R p .1 .714 .883$ \\
\hline Earning After Tax (EAT) & Rp.169.773.951 \\
\hline
\end{tabular}

Sumber : Data Primer diolah, 2019.

Pada penghitungan manajemen keuangan, pendapatan sebelum bunga dan pajak (Earning Before Interest and Tax - EBIT) menunjukkan selisih antara penerimaan dengan biaya produksi sebelum dikurangi dengan suku bunga ataupun pajak. Suku bunga yang dimaksud adalah apabila sang pemilik usaha mendapat modal tersebut dari hasil pinjaman. Pada penelitian ini, pemilik usaha tidak menggunakan pinjaman untuk modal usaha, maka dari itu pendapatan tidak dikurangi dengan suku bunga. Hal ini menunjukkan kondisi keuangan yang baik, karena berdasarkan hasil penelitian Utomo et al (2015) dimana seringkali suku bunga bank lebih tinggi dibandingkan profitabilitas peternak, sehingga keuntungan yang diperoleh kecil. Pendapatan setelah pajak (Earning After Tax) yang diperoleh pada usaha peternakan ini adalah sebesar Rp.169.773.951 dalam kurun waktu 1 tahun. Menurut Zuhairoh et al (2019), Pendapatan setelah pajak menunjukkan selisih dari penerimaan dengan pengeluaran ditambah dengan pajak penghasilan. Dalam penelitian ini, peneliti menggunakan nilai pajak $1 \%$ dari pendapatan untuk penghitungan. Hal ini sesuai dengan Peraturan Pemerintah Nomor 46 Tahun 2013 tentang Pajak Penghasilan atas Penghasilan dari Usaha, yang menyebutkan bahwa besaran pajak bagi peternak ayam adalah $1 \%$ dari omzet penjualan setiap bulan, dengan nilai omzet dalam 1 tahun dibawah Rp.4,8 Miliar.

Maka dari itu, penghitungan Operating Cashflow dengan modal sendiri adalah :

Operating Cashflow = EAT + Depresiasi

$=$ Rp.169.773.951 + Rp 512.166,65

$=$ Rp. $170.286 .117,65$

Berdasarkan hasil pengamatan, nilai arus kas pada usaha peternakan ayam broiler milik bapak Sariman adalah sebesar Rp.170.286.117,65 per tahun. Nilai tersebut merupakan hasil dari penjualan dikurangi dengan biaya operasional dan depresiasi. Biaya bunga dan pajak tidak diperhitungkan karena usaha ini menggunakan modal sendiri dan didirikan di lahan pribadi. Arus kas 
memperlihatkan akttifitas dari aktiva masupun pasiva dalam kurun waktu tertentu. Hal ini membuktikan bahwa dengan nilai arus kas tersebut usaha bapak Sariman termasuk dalam kategori sukses dan menguntungkan karena dapat menjalankan usahanya selama bertahun tahun secara berkelanjutan. Namun memang dalam pembukuan akuntansi, perlu diperbaiki lebih. Karena akan meminimalisir segala bentuk kerugian yang disebabkan oleh loss dalam proses usaha. Hal ini sesuai dengan hasil penelitian oleh Astuti (2010) yang menemukanbahwa mayoritas pengusaha peternakan unggas tidak melakukan pencatatan keuangan sama sekali, hanya berdasarkan pikiran saja berapa omzet penjualan, ongkos dan laba/rugi yang dihasilkan. Padahal bagi semua bidang usaha baik mikro, kecil, menengah, maupun besar, harus melakukan manajemen keuangan dengan baik dan dilakukan pencatatan, sehingga mampu mengetahui kondisi usaha tersebut

\section{KESIMPULAN DAN SARAN}

\section{Kesimpulan}

Pada kurun waktu 1 tahun, usaha tersebut rata-rata mampu panen sebanyak 8x dengan produksi sekitar 30.000 ayam dan memperoleh pendapatan bersih sebesar Rp Rp.171.488.834. Nilai Pendapatan setelah dipotong pajak sebesar Rp.169.773.951 dan nilai arus kas (operating cashflow) sebesar Rp.170.286.117,65. Dalam penentuan klasifikasi klaster, usaha ini tergolong kedalam klaster peternakan skala kecil, karena tergolong kedalam peternakan skala I yang mempunyai populasi ternak sebanyak $\leq 5.000$ ekor dalam 1 kali masa pembesaran. Namun peternakan ini tetap mampu menghasilkan keuntungan setiap kali panen, mampu melanjutkan produksi dengan modal dari keuntungan usaha dan layak untuk mengembangkan usahanya karena kondisi keuangan yang sehat. Selain itu, dapat disimpulkan juga bahwa usaha peternakan ayam broiler dengan pola kemitraan intiplasma skala kecil pada umumnya tidak melakukan pembukuan maupun pencatatan keuangan menyeluruh terhadap arus kas usahanya.

\section{Saran}

Proses pembukuan keuangan usaha peternakan dalam skala apapun sebaiknya lebih diperhatikan, mengingat dalam suatu usaha diperlukan pecatatan yang rinci terhadap segala pengeluaran, pemasukan dan kebutuhan yang sekiranya penting dalam keberlangsungan usaha tersebut. Pembukuan akan meminimalisir losses atau kehilangan yang tidak perlu, yang berpotensi mengurangi pendapatan akhir suatu usaha. Untuk peternakan skala kecil, memang umumnya tidak memiliki pembukuan yang baik. Namun apabila ingin memperbaiki dan mengembangkan usaha, sebaiknya memiliki pembukuan yang baik karena jumlah populasi dan investasi akan bertambah, sehingga potensi kerugian juga akan lebih besar apabila tidak dikelola dengan efektif dan efisien.

\section{REFERENSI}

Astuti. (2010). Perlunya Penerapan Sistem Akuntansi Pada Usaha Kecil Menengah. Jurnal Ekonomi Dan Kewirausahaan, 10(2), 152-163.

BPS. (2017). Produksi Daging Unggas Menurut Kabupaten / Kota dan Jenis Ternak di Provinsi Jawa Tengah (pp. 217-222).

Edwina \& Cepriadi. (2007). Analisis Usaha Peternakan Ayam Broiler Pola Kemitraan Di Kota Pekanbaru. Jurnal Petemakan, 4(1), 20-29.

Fadilah. (2012). Panduan Lengkap Sukses Beternak Ayam broiler. Penebar Swadaya.

Fatoni. (2014). Pengantar IImu Ekonomi (Dilengkapi Dasar-Dasar Ekonomi Islam). Penebar Swadaya.

Harjito \& Martono. (2010). Manajemen Keuangan. Ekonesia.

Jaelani, A., Suslinawati, \& Maslan. (2013). Analisis kelayakan Usaha Peternakan Ayam Broiler Di Kecamatan Tapin Utara Kabupaten Tapin. Jurnal IImu Ternak, 13(2), 42-48.

Jayanata \& Harianto. (2011). 28 Hari Panen Ayam Broiler. PT. AgroMedia Pustaka.

Kurniawati. (2012). Penerapan Akuntansi Pada Usaha Mikro Kecil Dan Menengah (Umkm). Jurnal Manajemen Keuangan, 10(2), 1-10.

Nurmi A, M.A. Santi, N. Harahap, M.A. Harahap. (2018). Persentase Karkas Dan Mortalitas Broiler Dan Ayam Kampung Yang Di Beri Limbah Ampas Pati Aren Tidak Difermentasi Dan Difermentasi Dalam Ransum. Jurnal IImiah Peternakan Terpadu, 6(3), 134-139.

Paly. (2016). Analisis Profitabilitas Peternakan Broiler Pola Kemitraan Berdasarkan Skala Kepemilikan Di Kecamatan Bontonompo Kabupaten Gowa. Jurnal IImu Dan Industri Perternakan, 3(1), 64-78. 
Pemerintah Republik Indonesia. (2013). Peraturan Pemerintah Republik Indonesia Nomor 46 Tahun 2013 tentang Pajak Penghasilan atas Penghasilan dari Usaha yang Diterima atau Diperoleh Wajib Pajak yang Memiliki Peredaran Bruto Tertentu.

Ratnasari, R., Sarengat, W., \& Setiadi, A. (2015). Analisis Pendapatan Peternak Ayam Broiler Pada Sistem Kemitraan Di Kecamatan Gunung Pati Kota Semarang. Animal Agriculture Journal, 4(1), 47-53.

Subkhie, H., Suryahadi, -, \& Saleh, A. (2012). Analisis Kelayakan Usaha Peternakan Ayam Pedaging dengan Pola Kemitraan di Kecamatan Ciampea Kabupaten Bogor. MANAJEMEN IKM: Jurnal Manajemen Pengembangan Industri Kecil Menengah, 7(1), 54-63. https://doi.org/10.29244/mikm.7.1.54-63

Suwarta, Irham, H. (2012). Struktur Biaya dan Pendapatan Usaha Ternak Ayam Broiler di Kabupaten Sleman Cost Structure and Revenue Livestock Broiler Chickens in Sleman Regency. Jurnal AGRIKA, 6(1), 65-84.

Utomo, H. S., \& S. I. Saleh. (2015). Analisis Profitabilitas Usaha Peternakan Ayam Broiler Dengan Pola Kemitraan Di Kecamatan Limbangan Kabupaten Kendal. Animal Agricultural Journal, 4(1), 7-14.

Yemima. (2014). Analisis Usaha Peternakan Ayam Broiler pada Peternakan Rakyat di Desa Karya Bakti, Kecamatan Rungan, Kabupaten Gunung Mas, Provinsi Kalimantan Tengah. Jurnal IImu Hewani Tropika, 3(1), 27-32.

Zuhairoh, T.S Aji, M. Ardianto. (2019). Relevansi Nilai Inkremental Arus Kas Operasi Dan Laba (Earning After Tax) Terhadap Harga Saham. Jurnal Akademi Akuntansi, 2(2), 81-92. 